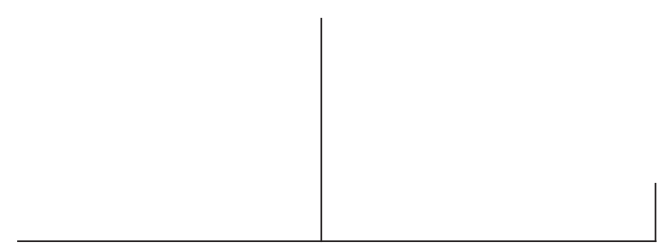

Rev. Latinoam. Psicopat. Fund., IV, 1, 51-75

\title{
A depressão na economia dos processos de diferenciação e integração psíquicas*
}

\author{
Daniel Delouya
}

\begin{abstract}
Interrogados sobre as questões atuais acerca da depressão - tema proposto para a primeira jornada desta revista -, o presente trabalho sugere que a depressão nos permite relançar as questões cruciais em relação à dimensão econômica do aparelho psíquico, integrando-a a outras, tópica e dinâmica, do mesmo. A depressão encontra-se no cerne de um princípio que, em analogia à biologia, condiciona e possibilita o surgimento da vida e sua permanência. Ou seja, abriga dentro dela um princípio paralelo ao que rege, na termodinâmica, a tendência negentrópica. Em outras palavras, ela conduz a construção da vida psíquica através das duas classes de processos que possibilitam, nesta analogia, a vida: diferenciação e integração. Alguns momentos e vinhetas clínicas são trazidos como ilustração desses processos.

Palavras-chave: Diferenciação, integração, quiescência narcísica, pulsão de morte
\end{abstract}

* O artigo é resultado de uma pesquisa clínica acerca da depressão que contou com o auxílio FAPESP (Proc. no 96/05391-0) pertencente ao Programa de Jovem Pesquisador em centros emergentes. Pesquisa que vem sendo realizada no Serviço de Psicoterapia do HC do Instituto de Psiquiatria da FMUSP em colaboração com o Laboratório de Psicopatologia Fundamental do Núcleo de Psicanálise do Programa dos Estudos Pós-graduados em Psicologia Clínica da PUC-SP, do qual o autor é pesquisador. 


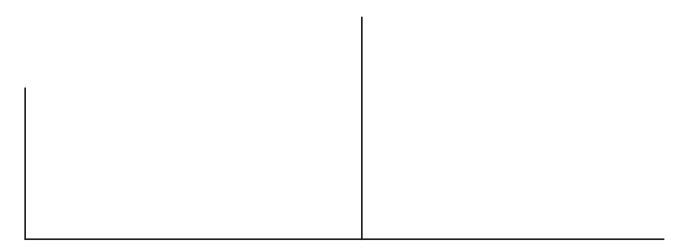

\section{Introdução}

O que é uma questão atual senão a luz que certo fenômeno, como a depressão, pode vir a lançar sobre a vida psíquica? Compartilho, portanto, a convicção com o grupo de psicanalistas que encontra na psicopatologia - e não tão-somente no texto freudiano - o gerador de perguntas e hipóteses, por meio das quais interrogamos o aparelho psíquico. O contato com o doente impõe-nos aquilo que é fundamental à psicanálise, ou seja, a escuta e a vivência da transferência. Nessa empreitada, a depressão ocupa um lugar especial. E se busco um modelo ou metáfora para descrever seu papel, não são os mitos de origem de Freud que me animam, mas o mais popular da ciência, fonte de hipóteses e pesquisas sobre as condições e as possibilidades da vida nas estrelas.

Os astros, seus enigmas e forças pairam sobre a psicanálise desde muito cedo, sobretudo a parisiense. O céu estrelado que acalentava o coração celibatário de Kant nas noites de Königsberg tem, parece, também exercido um fascínio e uma força de atração no famoso retorno de Freud em terra francesa. O desejo, que em Latim significa ir em direção a, ou orientar-se pela estrela, é inegavelmente central à psicanálise, apesar de Freud usar outro termo e imagem: Wunch (anseio) que remonta mais a sua fonte ansiosa - feita micélio - do que a qualquer indício de caráter vetorial. Os sistemas solares - e as galáxias que habitam - inspiraram, desde Freud, as imagens do sujeito como descentrado pelo inconsciente e pelo que implica, sobretudo na acepção de Lacan, de estrangeiro: o Outro, linguagem e cadeia significante. Traço esse que o estruturalismo matizou de constitutivo, determinando o sujeito desde o fora, ajusta-se bem ao papel da luz como fonte imprescindível para a biosfera. No entanto, as estrelas são incapazes de comportar a vida nelas mesmas já que geram luz ao se 


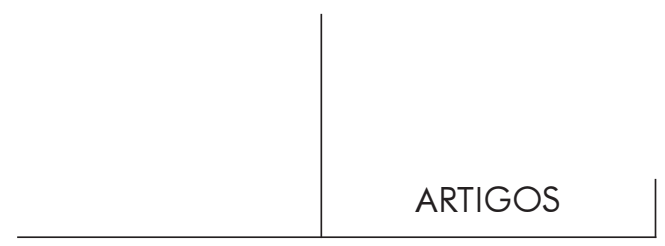

consumir, ao esvanecer. A vida nasce, brota e evolui somente naquelas que deixaram de estrelar e brilhar: nos planetas. Portanto, o que constitui (nesta metáfora da luz) a vida, vem de fora - como, aliás, na constituição de um estado e nação -, porém sua implementação na emergência, regulação e evolução da vida, é condicionada por meios e "materiais" próprios, do planeta. Para tanto, para que haja vida, é necessário que esses planetas tenham atmosfera, com uma composição ambiental que favoreça, junto à luz, não apenas a criação das moléculas primordiais da vida isso não é suficiente -, mas que sua geração, interação e contenção sejam conduzidas pelos princípios termodinâmicos, de forma que propiciem dois processos fundamentais: diferenciação e integração. A diferenciação é primeira; é ela que condiciona a integração, mas é a integração que garante, por sua vez, a diferenciação alcançada. Como exemplo, para tal analogia, cito o momento capital de diferenciação, no advento, segundo Freud, do auto-erotismo, em que, como procurarei mostrar, é a função depressiva que torna o corpo a morada da pulsão. ${ }^{1} \mathrm{Na}$ nossa pesquisa, a atenção clínica nos permitiu deduzir que a depressão conduz esses dois processos - diferenciação e integração - fundamentais para a construção psíquica. Portanto, para acrescentar mais uma fórmula ao quase saturado mercado de enunciados sobre o psiquismo, eu diria que a depressão é para o psiquismo o que é, e foi, a atmosfera elou o ambiente na emergência e evolução da vida. A depressão configura o psiquismo como ambiente; o humor depressivo sua meteorologia.

\section{Esclarecimento metodológico}

A distinção anterior, entre constituição, de um lado, e construção (com seus materiais e meios), de outro, tem uma particularidade que destoa do seu sentido corrente na literatura psicanalítica. O que pede, portanto, uma explicação adicional àquela fornecida em formas evocativa e alegórica.

Imersos no universo psicológico, nossa descrição e entendimento do outro acabam sendo, imperceptivelmente, banhadas nele. O psicológico é, no plano intersubjetivo, o nível imediato, da consciência, que repousa sobre um outro, indireto, da vivência ("creio que o paciente vive isso..."). O último nível, o da vivência, sobrepõe-se ao mundo das representações ao qual se tem acesso por meio da escuta flutuante da transferência, permitindo abstrair dessa massa psicológica o sentido que a rege, colocando-o a mostra. Sentido imanente à estrutura da linguagem (a cadeia significante) e à negatividade que lhe é inerente. Trata-se do regime consti-

1. Cf. A última parte do terceiro ensaio do livro Três ensaios obre a sexualidade, intitulada "Reencontrar o objeto", p. 77. 


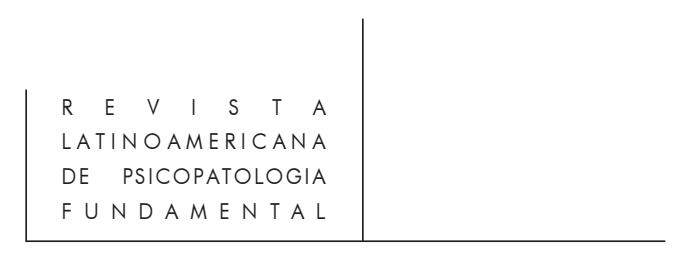

tutivo em que se inscrevem as coordenadas invisíveis, estruturantes do Édipo e da castração do ser da cultura. Existe, na psicanálise, um outro discurso de sentido, oriundo, de um lado, da hermenêutica e, de outro, da semiótica e da semiologia. Esse difere do primeiro, pois é, em certo sentido, oposto ao da cadeia significante, já que se pauta pela positividade dos signos que se reúnem, como na análise literária, em uma configuração de sentido esboçado ao longo de uma série de significados afetivos. Nesse caso, é a prática da tradução, ou melhor, da decifração que se coloca em marcha. Refiro-me à técnica kleiniana cuja inspiração por essas fontes fora reconhecida nos escritos de Donald Meltzer (1986), assim como, e sobretudo, de forma mais consistente, na transmissão de Isaías Melsohn (1991). Ao lado dessas duas classes (psico/fenomenológica e do sentido) com suas diferentes vertentes, existe uma terceira que constitui o eixo central da metapsicologia freudiana, do aparelho psíquico, e suas três dimensões - tópica, dinâmica e econômica - ao qual acrescentamos uma quarta, do tempo. Neste caso, a lógica não se reduz, por inteiro, ao plano simbólico, da linguagem. As funções e os espaços, com suas feições teleológicas adquirem um estatuto análogo a que se constata na biologia. A imaginação de tais modelos é tributária de uma metapsicologia, de um deslocamento do plano psicológico. Um deslize constante entre esses e o plano fenomenológico da vivência os colocaria a serviço da eficácia simbólica, da linguagem, em que desenrola a - ou em relação ao qual avaliamos o desenrolar da - cura analítica ${ }^{2}$. Por exemplo, referimo-nos muitas vezes à necessidade de conter, de haver continência, da sensibilidade ao sofrimento do paciente etc., como condições de acesso à fala. Para que essa intuição, ou dado "empírico", não se limite a uma mera injunção técnica ou uma descrição de um bem fazer da cura, é preciso conceber seu lugar na teoria. Veremos que essa é herdeira daquilo que denominamos de função depressiva, passível de ser articulada somente nas dimensões do aparelho psíquico freudiano. O campo psíquico, da linguagem, repousa e se sustenta sobre outro plano: "Ao abrir a porta da casa vejo aí, na sala, meu marido e filhos, não encontrando mais com os mesmos, e nem com o ambiente da casa, familiaridade alguma" narra-me, em um ar de tristeza, uma paciente em seu terceiro ano de terapia. Gênero descritivo esse que não cessa de atrair o "sábio" julgamento de alguns colegas que nos advertem sobre o perigo de se capturar no campo imaginário, na sugestão ou sedução do paciente etc. Não obstante, é a atenção à vivência ou sua continência que possibilita a abertura sobre as representações do paciente e, por meio delas, o manejo da cura. Nessa paciente, a dificuldade em efetuar o luto, a defesa e o temor diante da assunção da posição feminina, de desejo, são todos responsáveis pelo estado em que se encontra. Entretanto, é somente o reviver - a sensibilidade e a

2. Razão pela qual Pierre Fédida tem prezado a descrição fenomenológica. 


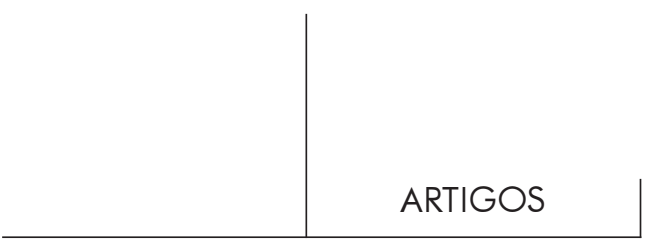

possibilidade de acolhê-lo - que permite o acesso progressivo em direção ao desejo e à castração. Novamente, são as dimensões relativas ao aparelho psíquico, sobretudo as econômicas, que condicionam a abertura para o universo simbólico da fala e da psique.

Para finalizar esta nota preliminar, diríamos que são as feições do aparelho, sobretudo as econômicas, que subentendem, fundam e condicionam o universo simbólico, como, aliás, demonstram as falhas do último, por exemplo, na irruptiva atuação pulsional, na passagem ao ato, do paciente e analista. Freud refere-se, já em sua obra inaugural, A interpretação dos sonhos, a processos, sistemas etc., algo que tem sido ignorado por aqueles que tudo querem assimilar no plano simbólico. Os processos secundários, diz Freud, devem-se a uma quiescência energética, desinvestimento, um tipo de desaceleração, freio ou oposição vetorial que se coloca como cunha ou fenda no interior da descarga pulsional direta dos processos primários. É essa tendência, de contenção, que se tornará a condição do recalque, de ligação às palavras, da consciência, do pensar, da inibição dos fins da pulsão, da sublimação, entre outros. Se nosso acesso a esses fenômenos se forma no interior da linguagem, é somente na imaginação dos modelos energéticos que se concebe o papel abrangente dessa quiescência - que Freud assimilará a partir de 1920, à ação silenciosa da pulsão de morte - na psicopatologia, sobretudo a depressiva, assim como na vida psíquica.

\section{Depressão e função depressiva}

As sequiências e descrições clínicas no texto que se segue visam apenas ilustrar a distinção entre vários níveis de realização da função que atribuímos à depressão, de delimitação e preservação do terreno psíquico. Contudo, o objetivo das notas gerais anteriores é frisar que a depressão relaciona-se menos com o discurso de sentido dentro da psicanálise, do que com o que o transcende e o funda, ou seja, a economia do aparelho psíquico. Essa que foi marcada pelas consequiências na vida psíquica do que Freud tem, desde 1895, derivado dos princípios termodinâmicos. Nesse sentido, o resguardo da vida psíquica pela depressão devese à preponderância do princípio que rege o que ele denominou, mais tarde, de pulsão de morte, mesmo que sempre em relação - ou agindo sobre - às pulsões de vida. Portanto, o que tange a depressão, não é, na metáfora anterior, o céu claro e estrelado, que ressuscitou o novo mensageiro de Copérnico na psicanálise, mas talvez a neblina e o ar cinzento londrino, sob o qual Winnicott (1995) redigiu, em 1963, um dos mais instigantes, embora coloquial, ensaios sobre a depressão, em que demonstra seu grande valor para a clínica das neuroses, psicoses e/ou a psicossomática. 


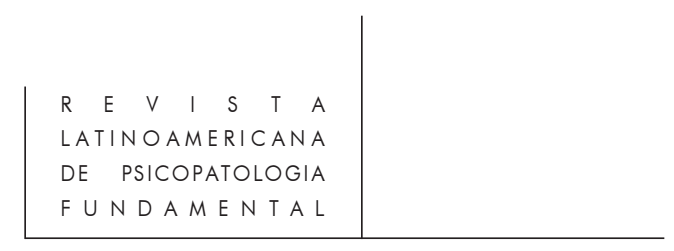

Na vivência com o paciente em depressão, e mesmo com o mais grave, há momentos privilegiados, cuja visada tendemos a perder de vista, nas quais se pressente um movimento bem peculiar, que Winnicott evoca por meio de duas imagens em relação à guerra. Quem viveu a guerra, não como soldado, mas sobretudo como criança ou jovem adolescente, identificará, junto ao deprimido, a agonia ao entardecer, o medo no cair da noite, quando a contenção silenciosa, na eminência de uma catástrofe, prende o corpo e marca o rosto; uma espera ansiosa e infindável varrendo a noite, sem notícias, aguardando e acompanhando, tenso, o tecer dos fios da luz da aurora, do nascer do sol. Pois a verdadeira guerra, aquela que é significativa, se faz na escuridão ou sob os densos nevoeiros e neblinas. Ao amanhecer, além de identificar os sobreviventes e lamentar as vítimas, constata-se novas posições do exército, novo arranjo das tropas; as fronteiras deslocaram-se, são outras: houve um remanejamento, um rearranjo, uma reorganização.

Existem, é verdade, outros, muito diferentes e impressionantes cenários de guerra - à luz do dia - como aqueles retratados em filmes do estilo de Steven Spielberg; que evocam uma análoga exposição nos dilacerantes cenários das vivências alucinatórias do esquizofrênico, para cujos desenhos remeto o leitor às finas descrições de Harold Searles (2000). Comparação valiosa para o entendimento da vivência junto ao deprimido. Convívio que se torna possível quando enxergamos que o sujeito está fechado para balanço, ainda que esse tempo fechado possa ter a duração de uma vida inteira. No último caso, a vitalidade precisou permanecer encoberta por um tempo indeterminado.

Poucos ainda lembram das duas décadas em que a literatura psicanalítica, sobretudo a americana, estava repleta das chamadas depressões de máscara e/ou de depressões mascaradas. Essas sumiram do mapa quando o incentivo para tirar as máscaras depressivas ficou a cargo de novos e potentes anti-depressivos. Nossos pacientes trazem notícias sobre as novas administrações de psicotrópicos, transcendendo o domínio do psiquiatra para o do neurologista, endocrinologista, ginecologista e até o do clínico geral.

O papel da depressão no resguardo, alerta e cura do psiquismo, necessita, portanto, de um novo impulso para voltar a descobrir seu lugar nas engrenagens do aparelho psíquico freudiano. Referi-me anteriormente, neste sentido, à diferenciação e à integração. Passo a indicar, por breves ilustrações clínicas, algumas de suas feições e modalidades associadas a estágios da genealogia psíquica. Tratamse de exemplos relativamente simples e diretos, extraídos de um livro, em fase de conclusão, que nasceu de um trabalho na instituição e junto ao Laboratório de Psicopatologia Fundamental da PUC-SP. 


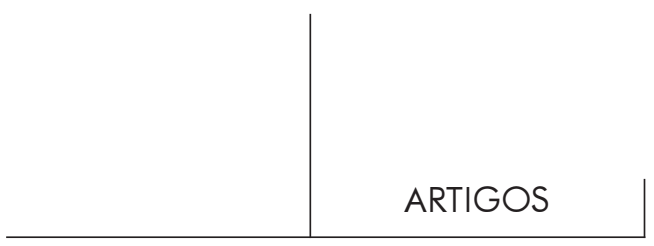

Diferenciação

Patologias e estados agudos de depressão, sobretudo os vizinhos da psicose, lançam nova luz sobre a função primária da depressão de delimitar e conservar o terreno psíquico de base. Maria, com estrutura manifestamente depressiva (já citada em um trabalho anterior; Delouya, 1998), nos apresenta uma série de variações de uma sequiência típica que demonstra a baixa resistência de seu estado de humor: "eu estava bem, quando no caminho para cá, esperando a chegada do vagão do metrô, ouvi um passageiro reclamando para seu colega sobre a piora de seus negócios". Na sequiência de situações desta natureza, a ameaça de um colapso físico, acompanhado de sensações de fraqueza e de perda da consistência corporal, advém junto a um estado depressivo, de reclusão e isolamento. Após alguns anos de análise, Maria cria sonhos que permitem, em seu desencadeamento associativo, vislumbrar cenários da infância que delineiam o contexto dessa deficiência de referências internas. Questionamo-nos muitas vezes sobre a economia daquilo que transparece, nesta paciente, como defesa depressiva que abafa, silencia e "mascara" o vivo psíquico, graças ao fracasso em assimilar os ruidosos mundos, pulsional e sensório, dentro da malha comum do conflito psíquico. Trata-se, pergunto, de uma carência de "referências" internas, colunas ou postos no Eu, que, segundo certa interpretação (Green, 1966/7), são obra do auto-erotismo ${ }^{3}$ ? Ou trata-se de uma deficiência mais básica, de uma estrutura que as enquadra e ancora?

Para situar essa questão, uma exposição teórica faz-se necessária. Antes, porém, mais um comentário sobre a paciente: impressiona como Maria manteve uma depressão característica durante mais de 40 anos, sem registro algum de episódios psicóticos ou alucinatórios salientes, embora a custa de uma pobreza afetiva e representativa; uma baixa generalizada da libido, acompanhada, ao longo dos anos, de complicações físicas ocasionais ${ }^{4}$. Seria interessante examinar a questão colocada comparando essa função depressiva em outra paciente, Elena, de 45 anos, que não teve a mesma "sorte". Nesta paciente, o escudo depressivo (configurado dentro daquilo que a psiquiatria denomina de transtornos de personalidade borderline), não se formou e não se instalou, como em Maria, como farda caracterológica, mas

3. Visão essa encontrada no clássico (1966) “Narcisismo Primário: estrutura ou estado?”, in Narcisismo de vida, narcisismo de morte, é condizente com a idéia, novamente econômica, de uma interiorização ou instalação dos registros do prazer.

4. Conclusão à qual chegamos após cinco anos de análise com a exceção, talvez, de uma de suas primeiras queixas que a levou ao neurologista 42 anos atrás: um ruído nos ouvidos que foi diagnosticado como defeito congênito de um nervo. Barulho que se agravava em períodos depressivos agudos. Entretanto, nos anos que eu a acompanho essa queixa não mais se manifestou. 


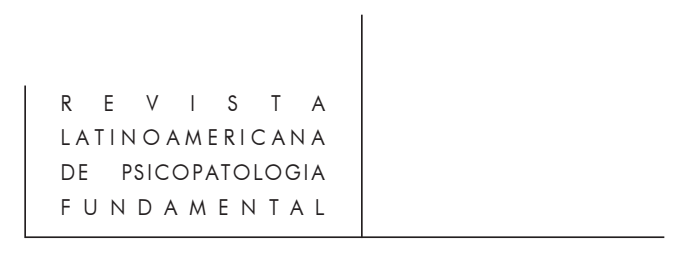

parece, freqüentemente, trincado ou rompido por ameaças - no limite da alucinação psicótica - entremeadas de estados histéricos de apelo e de tentativas suicidas. Não obstante, Elena dispõe de recursos psíquicos maiores; é mais "viva" do que Maria! ${ }^{5}$ A sequiência clínica a seguir é típica de uma modalidade defensiva do recurso depressivo em Elena, apesar das peculiares circunstâncias em que se desenrola:

No início de uma sessão, Elena verifica, ansiosa, se já me inteirei da notícia sobre a morte trágica da psiquiatra que lhe designaram um mês atrás. A residente, de 29 anos, foi encontrada morta, em razão de uma disfunção pulmonar, tornando-se fatal... detalhes que Elena me narra com certa aflição que aumenta com a percepção da minha dificuldade em identificar a pessoa a qual se referia... Nos minutos em que sou entregue a essa atividade silenciosa - que me possibilita, através dos dados fisionômicos aos quais Elena me reporta, reconhecer finalmente a pessoa de quem se tratava - a tênue tensão com que Elena acompanhava minhas expressões faciais, libera nela, com a minha identificação, uma expressão de meio choro, braços estendidos a meio caminho, suspensos no ar, no espaço vazio, como criança desesperada a procura de um colo... "O que vou fazer agora..." pergunta, chorando, ao qual respondo, reativa e imediatamente, com a frase "você está viva; nós estamos vivos, ela morta”. Intervenção que me causa um profundo desgosto, exigindo-me um esforço de voltar a examinar a imagem que passou fugidia em mim antes da minha "tentativa" de reasseguramento. Verifico, então, que se tratava de um fantasma de destruição do corpo: a evocação da médica em minha memória fundiu a imagem de seu corpo com o meu, colocando-me sob a ameaça de extinção, de destruição do próprio corpo. Reconheci, portanto, a moção defensiva (depressiva) da minha intervenção inicial. A integração dessa imagem de aniquilamento levou-me, então, a interpretar o temor da paciente como ameaça da perda nela de um suporte próprio. O agito que ela manifestou cessa em seguida à nova intervenção. Instala-se nela um ar depressivo em que passa a expressar suas preocupações com os problemas de coluna da sua mãe. Conta-me também que estava bordando um tapete que pretendia oferecer de presente para a médica que faleсеи...

A depressão ergue-se em Elena em reação a uma ameaça - de aniquilamento - sobre a estrutura de base, do enquadramento do terreno psíquico. Na vivência transferencial, esta ameaça exerce uma força de apelo sobre o objeto para que esse acoberte, forneça um revestimento ou suplemento a este enquadre. Foi Elena quem

5. No entanto, Elena é mais limitada em função da aliança de sua depressão com um conjunto de circunstâncias que são aparentemente exteriores: uma história psiquiátrica institucional bastante longa junto a uma forte vigilância familiar. Em seu universo psíquico, esses funcionam como uma dobra ou cobertura depressiva secundária. Maria, por outro lado, ao passar grande parte de sua vida em um âmbito religioso, tem-se "beneficiado" de um verdadeiro abrigo para sua depressão, que é, em certo sentido, oposto ao de Elena. 


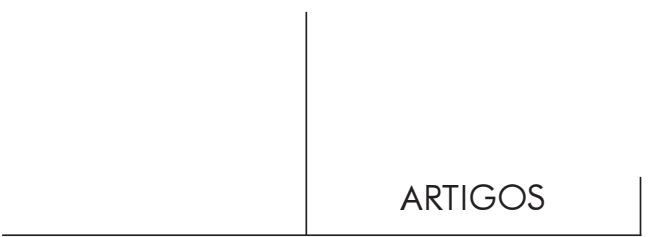

evocou, em suas associações, a coluna e a grade sobre a qual trança-se o bordado das vivências psíquicas. Estrutura de base que se preservou em Maria. Nessa paciente, não se trata da ameaça sobre o conjunto psíquico, mas de uma carência interna de referências ou registros (qualitativos) próprios, auto, de prazer. Nos momentos raros (após um certo trabalho feito) em que Maria desperta de sua depressão, surge nela um anseio forte pelo outro, "pelo seu abraço" - quer ser tocada e tocar - como se descobrindo e reforçando a "pele interna", situando-a a distância de seus buracos negros sobre os quais mantém, via de regra, uma rigorosa vigilância depressiva. Já em Elena a precária rede em que se inserem tais "colunas" não é capaz de conferir-lhes um assentamento perdurável. Entretanto, a distinção que estabeleci entre enquadre e as referências auto-eróticas que o encarna, não implica sua formação em ordem linear e sucessiva.

A atenção ao padrão de vivências das duas pacientes, associadas às suas depressões, permitem postular e distinguir duas diferenciações majoritárias na vida psíquica. Uma que figura o espaço ou o território psíquico basal, inicial, e um outro, que diz respeito a seu mapeamento interno, ou seja, às referências internas auto - sempre comto registros ou indícios de prazer, que dão ao sujeito uma noção sobre seu corpo, o psíquico. Na ausência ou malformação desses últimos há um recuo para o terreno inicial - um enclausurar-se dentro da "caverna", que aparece, como em Maria, como farda depressiva caracterológica. Por outro lado, falhas na constituição do espaço ou terreno psíquico basal colocam os conteúdos que abriga sob uma sensível exposição - precária soberania - tornando-o sujeito à invasão e evasão constantes, tão aparentes nos fenômenos psicóticos. É essa configuração fenomenológica, de inconstância, que Elena nos apresenta à semelhança de terras de ninguém em que se encontram assentamentos humanos esparsos, desligados uns dos outros. As seqüências clínicas indicam, claramente, o papel do objeto na instauração dessas duas e conexas dimensões. A função do objeto na instauração das colunas auto-eróticas tem sido bastante elaborada na tradição freudiana. Quanto à instauração do terreno psíquico de base, o papel do objeto tem sido enfatizado na obra de Winnicott, que Green integrou, de uma forma mais explícita, à obra de Freud $^{6}$.

A estrutura enquadrante, cuja preservação evidencia a depressão, remete àquilo que tem ocupado o centro do pensamento de A. Green (1989: 35) em torno do narcisismo primário: a tela vazia da alucinação negativa como estrutura enquadrante - molde e possibilidade, não representáveis, de toda e qualquer representação; rede sobre a qual se inscreve o mundo psíquico. Sua afirmação de que a "mãe é tomada no quadro vazio da alucinação negativa, e torna-se estrutura enquadrante

6. Ver mais adiante as citações correspondentes. 


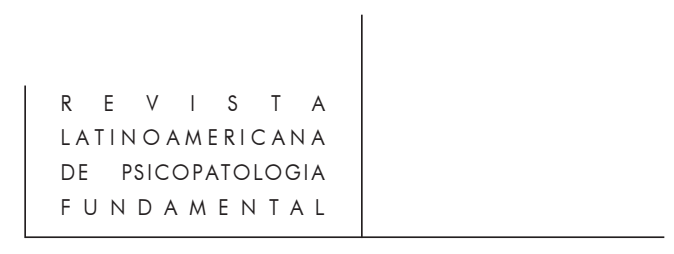

para o próprio sujeito", faz pensar que a mãe é convocada a acobertar, sustentar e responder ao estado em que se encontra o terreno psíquico inicial que descrevi, em trabalho anterior, como depressão originária. Ou seja, o próprio estado de desamparo. No entanto, os planos são diferentes: a tela remete à estrutura; o desamparo evoca um estado ou condição. Mas, na dimensão pulsional, o estado de desamparo resulta, dinâmica e economicamente, de duas tendências opostas: uma de expansão, centrífuga, oriunda das exigências pulsionais positivas, e da violência do mundo sensório - somada àquela oriunda do objeto, de sua paixão ou intrusão pulsional -, e outra, centrípeta, de inércia, encolhimento - o retraimento ao zero -, oriunda do princípio que rege a pulsão de morte, e cujo efeito sobre a primeira, das exigências ou pressões pulsionais e sensórias, é de conservação e preservação. O equilíbrio móvel, gerado por essas direções vetoriais opostas, traz a clara imagem da criação de um espaço. A depressão originária diz respeito à conservação desse espaço primitivo da psique.

Como no trabalho de Green, estamos oscilando entre a vivência ou os estados, associados, neste caso, à depressão, e a postulação de estruturas subjacentes. A estrutura, nós a assimilamos a uma configuração dinâmica, vetorial, das pulsões e do ambiente. Entretanto, essa última não é de todo satisfatória. Com a formulação do Nirvana entre 1920 e 1924, Freud $(1920,1924)$ nos fornece uma pista, um êxito que permite elaborar de forma surpreendente o tema da depressão em relação ao estado de desamparo. Pois o Nirvana figura, de acordo com sua raiz etimológica, tanto um estado de gozo passivo e a-temporal como, conforme a adoção feita por Freud, um princípio energético de entropia - uma tendência de reduzir as excitações ao mínimo, ao zero. Eis por que Freud (1924) faz derivar do Nirvana os princípios de prazer e realidade ${ }^{7}$. Aqui reside também o mito dos primórdios edênicos da vida.

\section{a) Nirvana ou a economia do mito, do psíquico}

A vida origina-se com o mito da "expulsão" do éden nirvânico. O desamparo é a instauração qualitativa de limites (dor) do e no tempo (angústia) e espaço (depressão). Limites que só têm sentido na articulação dialética com o não limite ou o ilimitado - espaço, tempo e qualidades de vivência - do nirvana mítico. Para cumprir este objetivo dentro desta ficção ou mito de origem, tomemos o referido ilimitado do nirvana não como uma expansão infinita, mas, como na física, como grau máximo, infinito, de condensação. Como essa semente ou grão virtual leva à criação da célula psíquica inicial que Freud empresta da vesícula ou bola protoplasmática?

7. O princípio da realidade é, segundo Freud, um princípio de prazer modificado. 


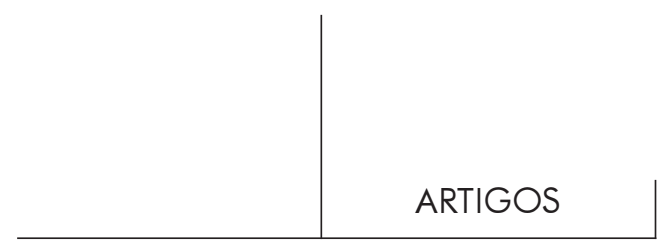

Com o advento da vida, "as necessidades vitais" (Freud, 1895), o mundo sensório e a paixão do objeto exercem uma pressão de expansão em função da resistência "natural", inerente ao encolhimento e retraimento da aquiescência narcísica do princípio e estado nirvânicos. O espaço que se cria é circunscrito, e grita: desamparo. Por que desamparo? "Quem" ou "o que" sofre tal pressão, ou melhor, tensão, criada pela distenção anteriormente figurada? O desamparo é sentido como tal não por um Eu herdado. Mas são os indícios de prazer que se pressupõem "embutidos" no Nirvana (Freud, 1924), tributários de uma consciência difusa de um eu-isso incipiente ${ }^{8}$. São esses os precursores das futuras referências auto-eróticas. Os aspectos dinâmicos e econômicos das forças em jogo encontram-se, portanto, indissociáveis dos qualitativos. Razão pela qual o nascer do espaço psíquico não é assimilável à metáfora da criação do universo pelo big-bang. É o potencial qualitativo, de registros de prazer, que dota a coesividade narcísica primária da consciência difusa da realidade (dor), de um território (depressão), e ameaça (angústia) advindo de forças que lhe são exteriores: "expulsão do éden”, desamparo?.

O nascimento é, pois, coextensivo ao desamparo, condição inextricável da vida, psíquica e biológica. A vida torna a ser um intervalo, uma faísca na eternidade mítica do nirvana. Se comparamos, imaginariamente, o nirvana - gozo da quietude, passivo e atemporal - ao estado, "autista" de uma reserva natural, a qualidade vital coincidirá com a visita de turistas que, ao explorarem-na, ao se banhar em suas águas as espalhariam, transformando as energias represadas ou inertes (círculos fechados de descarga "para dentro") em uma descarga para "fora", movimento, prazer... Analogia que ilustra por que o nirvana é pré-pulsional, e do qual se derivam as qualidades e o princípio do prazer e o desprazer (realidade) do viver (Freud, 1924).

O desamparo introduz um desvio do equilíbrio nirvânico. O espaço de tensão que cria tende a voltar ao estado anterior, de nirvana. Volta essa que, na ausência de satisfação, se manifesta como desinvestimento e retraimento, associados à quiescência do narcisismo primário. Não obstante, a satisfação das necessidades e a eliminação dos ruídos oriundos da pulsão e do ambiente regem-se pelo princípio nirvânico, da redução da excitação ao mínimo. O espaço de tensão - desamparo engaja a tendência nirvânica em outra obra, junto ao objeto: contém e precipita, em

8. Razão pela qual Freud supõe em 1938, no "Esboço de psicanálise", haver uma demarcação de consciente, pré e inconsciente antes de qualquer formação do recalque primário.

9. Sou grato ao Manoel T. Berlinck que me alertou, já no trabalho inicial em que atrelei a depressão ao estado de desamparo, sobre a necessidade de elaborar a função da dor. Ver nosso artigo “A dor entre o corpo, seu anseio e a concepção do seu objeto", in Berlinck, M.T. (org.). Dor, pp. 23-34. 


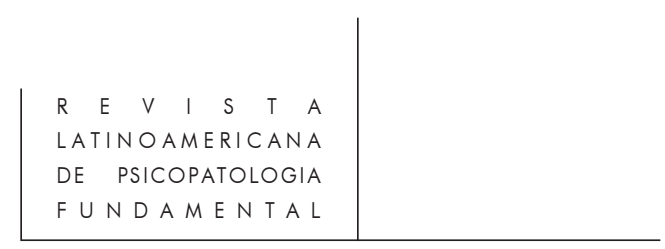

termos energéticos, o registro de um trajeto ao longo do qual as exigências vitais encontram sua satisfação. Esse traçado, o mnêmico, constitui a unidade básica da psique; é fruto de uma construção que se expandirá, com a experiência da realidade - de dor e satisfação - numa rede de trilhamentos que compõem as estruturas psíquicas do eu. Razão pela qual o nirvana como reserva - limiar de contenção da tensão prazerosa (uma descarga "para dentro") - foi, no modelo inicial de Freud, o protótipo do psíquico sob a forma de trilhamento de energia - portanto, represa$d a$ - no espaço da rede neuronal (Freud, 1895). Ou, mais precisamente, a abertura de espaço - consequiência das forças que motivam o desamparo - deturpa e distende a coesão nirvânica que acaba sendo "compensada", em parte, pelos trilhamentos gerados com a ampliação dos trajetos da experiência de satisfação, de seu "formato" de desejo.

Os últimos parágrafos exigem certo esforço do leitor em vista da nossa recusa em reduzir o nirvana a uma mera tendência ou mero princípio. As qualidades de um estado são indissociáveis da tendência, o que parece não se coadunar com o rigor e a coerência epistemológicos. Assiste-se, no entanto, essa bivalência desde 1895, já na formulação do princípio de prazer: como conseqüência de descarga de tensão assim como contenção da tensão sexual. $\mathrm{O}$ mesmo diz respeito à distinção entre pulsão e instinto em que Freud acrescenta à primeira uma qualidade: o representante da pulsão. O nirvana constitui-se no cerne da vida psíquica como eixo transicional entre feições econômicas e representativas.

Nas ilustrações clínicas aludimos para o papel do objeto. O desamparo torna o objeto o destinatário de certa reparação do distúrbio - de vida - introduzido no seio da mítica eternidade nirvânica. A identificação primária é a forma de tomar o mundo (o objeto em sua totalidade) para dentro do enquadre ameaçado do terreno dos inícios. Operação essa que fracassou em Elena. As bases energéticas para tal empreitada serão discutidas mais adiante. Essas dizem respeito ao foro afetivo, basal, do ser humano, costurado nos meandros da ternura. O mapeamento interno, no corpo psíquico, referente às vigas e colunas auto-eróticas seguem o mesmo princípio da restauração parcial dos registros oriundos da dimensão nirvânica. As funções e estruturas propriamente psíquicas têm como unidade básica o traçado mnêmico cujo liame com a energia ligada do nirvana já apontamos. Construção essa sobre qual economia estamos sobrevoando, se entrelaça à dimensão especular, amplamente discutida no âmbito psicológico do narcisismo. Aspectos que não serão tratados no contexto deste artigo.

Para resumir, evocamos Freud (1938) dizendo ser a vida psíquica "uma função de um aparelho ao qual atribuímos as características de ser extenso no espaço...”. Mas, do ponto de vista econômico, a extensão refere-se a um espaço de gozo, núcleo de energia quiescente - do narcisismo primário - que o princípio de nirvana assegura. O desamparo, porém, é consequiência de uma perturbação desse 


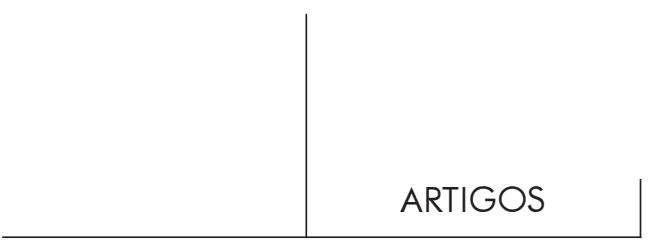

estado de nirvana, pois o nascimento implica a exposição desta vesícula psíquica de origem aos ataques vindos, de um lado, do mundo sensório, e, de outro, daqueles "liberados" pelas exigências pulsionais cuja sede Freud situa, em 1895, nas células nucleares e, a partir de 1923, no Isso ${ }^{10}$. A proteção contra essas forças brutas, de um lado, e a assimilação, sempre parcial das mesmas, de outro, no referido núcleo, em favor de uma complexidade, construção do futuro sujeito, é mediada pelo outro, pelo objeto. Percebe-se, então, como a idéia de depressão perpassa o tema da preservação e do desenvolvimento do incipiente universo psíquico. A depressão originária revela a função defensiva mantendo "os interesses" desta partícula ou grão de agregação originária perante a efracção sensória e pulsional ${ }^{11}$. $\mathrm{O}$ apelo ao objeto encontra-se no cerne desse estado. Porém, o ponto crucial sobre o qual gostaríamos de insistir é que a vinculação da depressão com o espaço de gozo refere-se à preservação de um terreno indiferenciado que transcende, portanto, os limites do recorte e da apreensão concomitante do Eu e objeto ${ }^{12}$. O "terreno" é uma região ainda indiferenciada do $E u$ - $I s s o^{13}$. Aqui reside toda a vantagem - e a ambigüidade, também - da formulação do princípio de Nirvana uma vez que este une a qualidade psíquica - um estado - com a economia que a subentende.

A predominância da tendência nirvânica aproxima a imagem da quiescência narcísica à indiferença que caracteriza, segundo Freud (1915), a relação primeira ao objeto, conjugada, na seqüência, ao ódio. No entanto, essa diferenciação primitiva do Eu deve ser concebida no conjunto mais amplo do campo primordial do

10. O nirvana como origem (mítica) e ordenador da vida psíquica é, portanto, uma dedução feita no a posteriori.

11. Eis um ponto de discordância com o trabalho de Elisa Maria Ulhôa Cintra acerca da depressão em que o retraimento do narcisismo negativo constitui um eixo central de seu desenvolvimento ("Estados depressivos na histeria e na neurose obsessiva", apresentado no Congresso Latino-Americano dos Estados Gerais de Psicanálise, 15 de Novembro 1999, São Paulo). A autora desvincula dessa linha de retraimento as moções destrutivas e masoquistas associadas com a pulsão de morte de Freud, ao passo que, em nosso desenvolvimento e experiência clínica, essas últimas são direta e dialeticamente conexas.

12. Visão bastante difundida graças ao seu elo com a noção freudiana da melancolia e com a formulação kleiniana da posição depressiva.

13. Ilustrado numa forma típica de vivência depressiva (Cf. Delouya, D. Depressão). Entre as suas anotações, descobertas em seus escritos póstumos, Freud considera estados associados ao narcisismo cósmico, de expansão e elação, como apreensões a posteriori do Isso. Em termos descritivos a noção do self parece mais apropriada. 


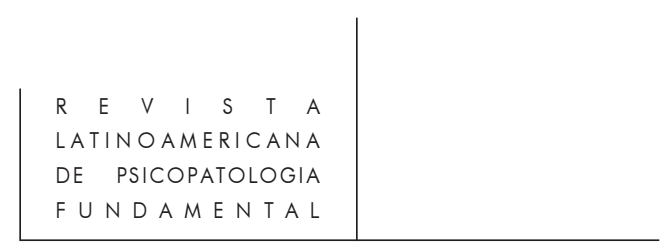

sujeito, a semelhança de uma infra-estrutura ou plano de uma futura cidade ou cultura autárquica. Nesse "terreno e ambiente selvagens", que a depressão primária tenta resguardar, existem, é verdade, "descendentes de tribos e reinos antigos", pouco diferenciados, como o pai filogenético - substrato identificatório independente de qualquer investimento (Freud, 1921 e 1923) -, o Eu-realidade primitivo, o Euprazer purificado, entre outros (Freud, 1915, 1921, 1923). Os últimos são os precursores iniciais das instâncias definitivas do Eu. A depressão primária referese, novamente, ao conjunto total, e ao ambiente que permeia cada uma de suas regiões e entidades. A ameaça sobre esse assemelha-se a um tipo de escassez ou de catástrofe ambiental que coloca toda a vida psíquica sob o perigo de extinção (o mito freudiano da era glacial é, neste contexto, de grande utilidade, sobretudo metafórica). É esta a fragilidade, de uma estrutura enquadrante, que Elena nos revela. Seria seu fracasso a conseqüência da falha do objeto em exercer certa função para a qual é convocado (Green, 1966/7) com o nascimento? Em que esta consiste? Sobre o que se funda? Trata-se, certamente, de um subsídio mais amplo e mais geral do que a formação da "crosta morta" de superfície - que pára as excitações, assim como fraciona os afluxos sensoriais - e/ou seu paralelo interno, embora não análogo: o auto-erotismo, como colunas auto-referenciáveis no Eu. Pois a ausência do referido suplemento enquadrante impediria o uso da alucinação negativa, como tela do trançar representativo. O que promoveria a dissolução dos "pontos de ligação" desta "rede" (em sua estase de quiescência narcísica), que constitui esse enquadramento, para seu puro excedente energético, decorrente da disfusão pulsional: uma catástrofe - angústia e terror inominável (Bion) - que a depressão primária não consegue prevenir.

As metáforas de ambiente, de estrutura enquadrante, de rede e tela dificultam, certamente, a transmissão do fenômeno em questão. Em trabalho anterior (Delouya, 1998) formulamos este estado em termos fenomenológicos e psicológicos, de demandas - de continente e conteúdo - articulados ao contexto especular, do corpo sob ameaça de destruição, e o universo que lhe é conexo, de projeção e fusão ao outro, total e íntegro. No entanto, aquele contexto não responde às indagações relativas ao aparelho psíquico. Pois no que tange à natureza da relação com o objeto nesses estágios primordiais do sujeito, Freud fornece descrições aparentemente contraditórias: acredita, de um lado, numa fusão com o seio da mãe; o bebê não apreende o corpo da mãe em sua totalidade e independente do seu. Uma diferenciação que adquire somente em um curso passivo ao termo do qual emerge, percebendo-se separado, em decorrência das frustrações, da ausência da mãe, e das desilusões que ela introduziu. Porém, em outros momentos, Freud postula uma separação desde o início, apoiada em uma tendência primária negativa (de indiferença e de ódio), que expulsa e excorpora, delimitando, assim, um Eu primordial do objeto, do outro. Moção orientada pelos precursores do Eu (Eu-realidade e Eu- 


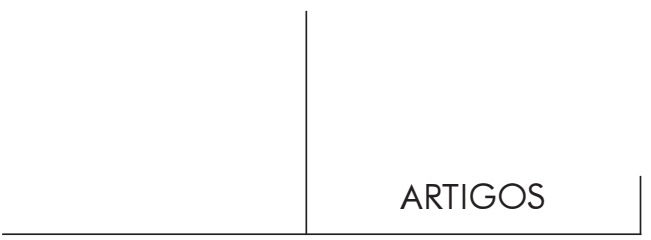

prazer purificado, entre outros), já mencionados, ao mesmo tempo que os reforça, tornando-os pólos de aglutinação das instâncias do futuro Eu $(1911,1915)^{14}$.

Entretanto, tais opções não são excludentes, mas, ao contrário, complementares. Uma passagem conhecida em Freud sobre o advento do auto-erotismo, ilustra uma articulação particular das duas opções. Momento constitutivo de extrema importância para o longo trajeto em que embarcamos, na tentativa de elucidar a relação entre a estrutura enquadrante, o ambiente e a função depressiva:

$\mathrm{Na}$ época em que a satisfação sexual estava ligada à absorção dos alimentos, a pulsão encontrava seu objeto fora, na sucção do seio da mãe. Este objeto foi posteriormente perdido, talvez precisamente no momento em que a criança se tornou capaz de ver, em seu conjunto, a pessoa a quem pertence o órgão que lhe proporciona uma satisfação. A pulsão torna-se, a partir de então, auto-erótica... (Freud, 1905: 228).

Freud distingue, nesta passagem, dois registros de percepção - e de existência - do seio. O primeiro refere-se ao seio como alvo de satisfação: na procura e no acesso a esta fonte, a percepção se constitui como correlato cognitivo a serviço da necessidade pulsional. Ou seja, para nós ou qualquer outro observador, o bebê vê o seio "lá fora". Entretanto, o seio se revela, a posteriori, como tendo essa função de satisfação no contexto, ou sobre um pano de fundo, que é o de um espaço de fusão, e de gozo, com o corpo da mãe. A percepção do seio efetua-se desde o ponto de vivência fusional, junto ao corpo da mãe. No entanto, a aquisição, segunda no tempo, do sentido que permeia e constitui tal percepção do seio "então, o seio pertence à mãe, corpo separado de mim" - advém em consequiência de uma verdadeira transformação: um processo em que uma parte do meio circunscreve-se, recortando e delimitando um corpo, de si e do objeto, e concomitantemente. Emergência que resulta ao cabo de um processo - esquematizado no "Projeto..." (1895) - de entrelaçamento complexo contínuo da reflexividade perceptiva, em relação às regiões e aos espaços do corpo da mãe, com a aquisição progressiva de seu sentido por meio dos indícios pré-conscientes de prazer/desprazer, concomitantes à emergência progressiva do estado indiferenciado com o objeto. O que constituía o meio passa a fazer parte do próprio corpo. Em outras palavras, o corpo toma o lugar daquilo que constituía o mundo/meio (Freud, 1938), ao qual o sujeito estava fundido. O auto-erotismo resulta de uma "introjeção" - a

14. Para a primeira, relacionada à emergência de uma fusão, veja Freud (1895) "Projeto de uma psicologia"; (1905) "Os três ensaios sobre a sexualidade"; (1926) "Inibição, sintoma e angústia"; e, principalmente, o último livro de (1938) "Esboço da psicanálise". Para a segunda, de uma diferenciação primária, veja (1911) "Formulações sobre os dois princípios do funcionamento psíquico"; (1915) "Pulsões e seus destinos"; e o ensaio de (1925) "Negação". 


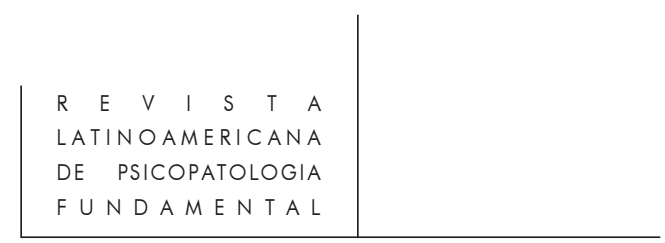

"colocação em território próprio" - e, portanto, o mapeamento do gozo e dos registros de satisfação dentro de si. (Daí, aliás, a força evocativa da noção do self.) "Aquisição" essa, do próprio corpo, se faz ao preço da perda do objeto, da mãe. Como se a depressão, a percepção da mãe como ente separado e, portanto, a aquisição de uma noção de estar separado da mesma ${ }^{15}$ - tornasse o corpo a morada da pulsão.

Na citação anterior fica claro que esta perda do objeto antecede e condiciona a do seio. Este cenário, em torno do seio, ocorre sobre um palco/tela, ou melhor, é fundido ao enquadre silencioso proporcionado pelo objeto. A transformação no bebê, da perda do seio quando da configuração do objeto, tem como consequiência a obtenção do prazer independente do objeto. Entretanto, se esta perda é definitiva, como acredita Freud, deve, por outro lado, se interiorizar coo tal, deixando, na memória do corpo, os traços e as pegadas do caminho de volta, do retorno à plenitude dos inícios. As "colunas" do auto-erotismo acabam servindo de marcos de apoio para esse infindável trajeto, embora jamais substituem, por inteiro, o papel e a função anterior junto ao objeto ${ }^{16}$. Nessa transformação, a diferenciação entre o sujeito e o objeto não é absoluta. O sujeito permanece dependente - associado ou fundido de alguma função que o objeto preenche. Como se o Eu não se apropriasse, ou "não levasse consigo", algo essencial daquilo que o objeto proporcionara no estado de fusão originária. E, como na imagem socrática de criação em que a figura nasce da pedra, a última continua servindo como suporte, tela de fundo e de origem, para a primeira. Uma configuração, ou melhor, a polarização figura/fundo, acaba potencializando a tensão em busca da plenitude originária, da homogeneidade fusional.

Essa breve consideração nos permite voltar para a questão da estrutura enquadrante. A pressão centrífuga provoca, por assim dizer, a resistência do núcleo quiescente, que faz este último "gritar", "chamar ou trazer para si", o que, no plano intersubjetivo, transparece como apelo. O terreno psíquico dos inícios torna-se, assim, o alvo de uma obra primária que denominei de terraplanagem psíquica. Essa corresponde, na vivência da primeira infância, à linguagem de ternura (Ferenczi, 1992). Pois o tornar-se o sítio da investidura do objeto deve-se aos ecos desesperados da moção centrípeta - os destinos que determinam as tendências passivas, $o$ retorno sobre si e a inibição dos fins da pulsão - que, segundo Freud, constituem

15. A consciência de estar separado é, como bem mostrou Klein (1935), por excelência depressiva.

16. São, portanto, pontos de referências, mapeados no e sobre o corpo, e que, no plano mítico, se assemelham aos sobreviventes isolados de um remoto reino, mítico, da fusão originária, do estado nirvânico junto ao objeto. Portanto são sinais de presença de uma falta ou dos vestígios da "coisa" perdida. 


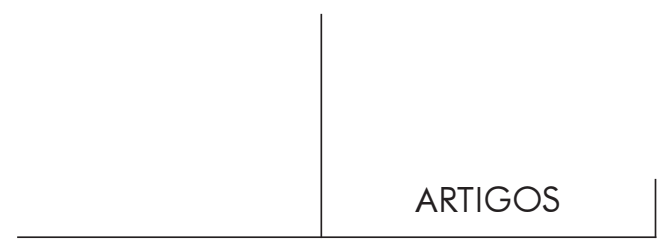

os primeiros elos de ligação, permanentes e perduráveis, junto ao ambiente (Freud, 1912).

A diferenciação primeira, do terreno psíquico selvagem, é o passo inicial da obra depressiva. Não é possível e nem é preciso pressupor aqui qualquer recalcamento primário. Freud assume, como assinalei existir, desde o início, os registros de prazer/desprazer, implicando a demarcação entre pré-consciente e inconsciente ao lado de descargas puras da libido ${ }^{17}$. Seria interessante pensar como o trabalho depressivo conduz a segunda maior e mais importante diferenciação em que esses registros serão transformados, encontrando uma morada no corpo psíquico. Trata-se, neste momento, da famosa instauração da pulsão como auto-erótica; o momento em que a pulsão passa a habitar o corpo. No qual a descarga direta do onanismo infantil e a sexualidade perversa polimorfa passam a ser postos em território próprio, do corpo. Freud (1905) nos diz que isso ocorre no preciso momento em que o sujeito se apercebe separado da mãe ou a enxerga como totalidade. Ele nos faz lembrar aqui da Melanie Klein, trinta anos mais tarde, na sua primeira formulação da posição depressiva (É ela que não lembra, neste contexto, de Freud). Ou seja, a circunscrição do corpo próprio, sua emergência da fusão junto ao objeto. Freud é mais nuançado aqui do que Klein ao afirmar que a criança percebe, neste momento, que o seio, ao qual se endereçava, pertence ao corpo da mãe do qual ele se apercebe, agora, estar separado. Em outras palavras, essa transformação, de cuja consciência inteira-se a posteriori, indica que o sujeito não deixou por completo a habitação do corpo da mãe, mas este parece ter recuado, passando a formar o enquadre, o fundo silencioso e os horizontes do ambiente psíquico do sujeito. Nota-se que, ao contrário da Sra. Klein, que desenha as coisas como se houvesse uma divisão celular simples - a formação de dois corpos, Eu e Tu - Freud permite pensar, com Winnicott, que o Eu é situado num ambiente. Uma totalidade polariza-se, diferenciando-se em figura e fundo. $\mathrm{O}$ sujeito emerge de um campo em que ele se define e se situa num ambiente, que é, também, conseqüência desta polarização. O ambiente é o meio que "se alastra" - uma espécie de gradiente desde a estrutura enquadrante até o corpo/Eu que incorporou as qualidades de prazer/desprazer que estavam presentes na fusão originária (Freud, 1905). Veja que essa formação deve-se a dois movimentos centrípetos: um em direção ao núcleo do Eu e outro para o enquadramento de base. O espaço e o gradiente assim criados instauram o palco do acontecer psíquico porque propiciam, com isso, uma tensão depressiva em que circula o desejo. Percebe-se como o modelo econômico articula, no plano da vivência psíquica, o desejo que tem sido amplamente discutido no plano da linguagem, da cadeia significante.

17. Segundo o "Esboço..." a diferenciação consciente/inconsciente antecede o recalcamento primário. 


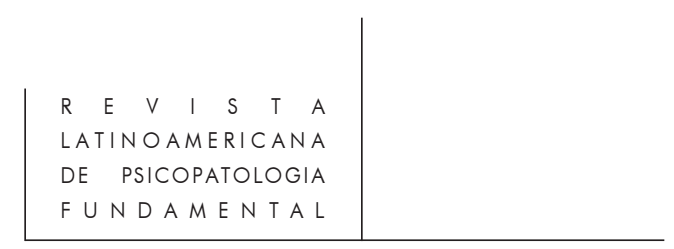

Uma discussão geral e abstrata, mesmo se recheada por metáforas de diferentes origens, talvez não consiga nos tornar sensíveis ao entendimento de como o destaque ou a circunscrição de um Eu coloca em xeque as estruturas do meio do qual emerge. Um aspecto particular do fenômeno infantil de medo de estranhos é, neste sentido, ilustrativo, principalmente em uma de suas edições tardias, em crianças ao redor de dois anos de idade. Notei, na última festa de Natal, crianças com esta idade, que manifestando tal medo em relação ao Papai Noel, evitando, durante um longo tempo após a sua ida, o espaço e a região em que ele se posicionara antes, na entrega dos presentes. Qualquer tentativa de trazê-los até o local que ele ocupava previamente, despertava uma resistência tingida de tremor e medo. Fenômeno este que adquiriu, recentemente, um sentido mais claro a partir de um incidente trágico na vida de uma paciente que está, atualmente, no seu oitavo ano de análise. Uma jovem mulher que vem tecendo em torno de sua problemática histérica uma rede criativa genuína, e extremamente versátil, para dominar o desejo, ou melhor, a angústia relativa à ausência do seu objeto. Problemática essa que remonta às cenas infantis em que as ausências da mãe defrontavam-na com um limite da capacidade de reter, naqueles momentos, os vestígios da presença materna.

Poucas semanas após a perda trágica de seu irmão, relata numa sessão que a amiga mais próxima, da mesma cidade natal, entrou em contato com ela, se desculpando pelo atraso em manifestar seus pêsames e solidariedade pela morte do irmão. A amiga confessa não ter conseguido somar forças ou ter coragem para fazê-lo, pois sentia, inicialmente, um temor do contato ${ }^{18}$. E acrescenta, "brincando", segundo a paciente, "nós duas somos ainda muito jovens". Minutos depois a paciente comenta que ela própria evitava e protelava, nesses dias, o contato, pelo telefone, com seus pais em luto que moram na cidade de origem: ela temia o contato. A paciente confia-me, em seguida, que ela se apercebe, nesses dias - logo após o incidente trágico - de novas atitudes nela como o medo de dirigir na estrada além de trancar, à noite, a porta de seu quarto: teme, parece, a invasão de algo... Espíritos? indaga-se, surpresa da crença, até então ignorada, sobre a existência de tais seres. Como se tal crença infiltrou-se nela, involuntariamente. Relata, então, o sonho da véspera na qual, no cemitério, alguém a advertia para tomar cuidado e não pisar sobre o túmulo do qual tomava conta, mas andar atrás das pedras, à sua volta... para não cair lá dentro ${ }^{19}$.

18. A conduta de evitar as proximidades da região que concentra os indivíduos enlutados pelo familiar que faleceu em circunstâncias trágicas não é, de modo algum, rara: ao contrário!

19. A narração do sonho e seu contexto evocou em mim outros sonhos da paciente, dos primeiros anos de sua análise, associado a temores da infância em relação ao cemitério da aldeia em que cresceu: ser puxada pelos mortos para baixo etc. 


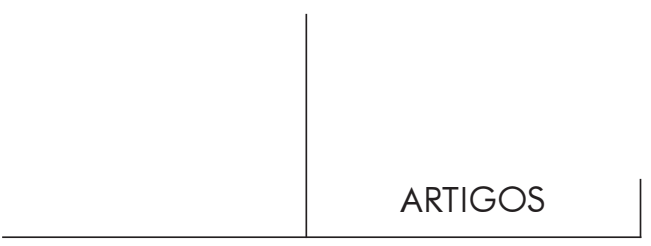

Essa sequiência ilustra por que Freud insiste sobre a perda definitiva do objeto quando da figuração inicial do Eu no ambiente psíquico. A depressão e o medo (angústia) erguem-se, nesse caso, como forças de retraimento, constituindo, respectivamente, uma garantia contra a invasão e a demolição da recente e delicada estrutura nascente do $\mathrm{Eu}$, assim como uma defesa contra a ameaça de uma inversão dos sentidos opostos dos vetores anteriormente descritos (um em direção ao Eu e outro, no sentido oposto, ao fundo da estrutura enquadrante). Assim, a depressão e o medo afastam a tendência fusional e a anulação da polarização do campo psíquico que significaria a volta para a homogeneidade e a indiferenciação, da morte. Fundo e figura articulam-se, aqui, mutuamente, mas é a suscetibilidade do fundo, da estrutura enquadrante, que ameaça a dissolução do Eu, e sua indefesa exposição à possível invasão vinda de fora (confusão de limites e suas ameaças). A configuração do Eu coloca em xeque a investidura do objeto, o revestimento do pano de fundo do ser, criado no decorrer do estado de fusão dos inícios junto ao objeto.

Entretanto, essa fragilidade e a denuncia de malformação na estrutura enquadrante, graças à deficiência no ambiente de fusão de origem, não é aparente em outras configurações depressivas em que uma tristeza denota, de um lado, o estabelecimento de uma disposição estável do Eu no ambiente psíquico, ao mesmo tempo que o último parece carecer de ingredientes que possibilitam a troca e o movimento. Uma paciente expressa em alguns de seus sonhos um pousar-se imóvel sobre um puro fundo que carece de conteúdos: uma enorme ave, imóvel, ou uma imensa árvore sem raízes nem folhas. Ambos situados em um ambiente estéril ou em um não-ambiente, um vazio, tela branca. Figura precisa do seu estado depressivo do momento no qual vive um silêncio imóvel - cheia de si em um grande vazio. O Eu parece se empanturrar do ambiente a ponto de não mais haver troca nem movimento; apenas peso e forma, embora com a presença de uma tensão aprisionada da vontade de voar e de se lançar para o alto.

O espaço não nos permite focar os grandes e pequenos momentos de integração inerentes à reflexividade - da vivência do movimento e apreensão afetiva, junto ao rosto e ao corpo da mãe, respectivamente - para qual deficiência atestam as depressões. Para finalizar, sigo com uma descrição clínica relacionada à vivência sensorial na depressão.

\section{Integração}

As diferentes vivências sensórias, peculiares ao estado depressivo, marcam sua presença, na análise, em forma evocativa da memória. Esta surge na esteira de um pressentimento de um possível ataque; como alerta da sobrevinda do estado temido. Isso já é, a meu ver, um indício de acolhimento, de certa integração do mesmo: 


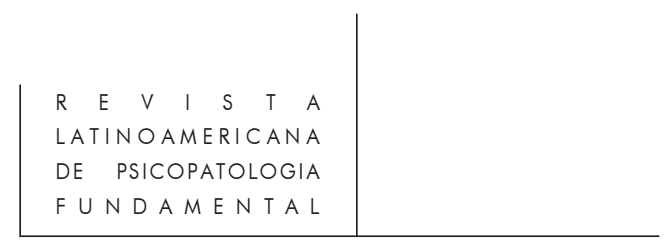

Ao entrar em casa, na volta de seu escritório, o paciente torna-se sensível a uma tonalidade peculiar da luz sobre a mesa da sala de jantar, levando alguns segundos antes de identificá-la como tal. O cenário familiar - a esposa à sua espera para o jantar, e a criança, que ele não havia encontrado desde a noite anterior, brinca animada no chão da cozinha - parece distanciado, como se tratando de um agito na casa dos vizinhos. $O$ ar de família se desmantela; perde sentido. É a luz amarela, espalhada sobre a mesa, que enche agora todo o espaço, expondo uma tela branca de sua existência que está prestes a esfarelar-se num verdadeiro vazio. A consciência do buraco depressivo dentro do qual o ambiente da luz ameaça aspirá-lo, surge associada à identificação desta tonalidade amarela numa vivência depressiva de anos atrás. O paciente traça a origem de todo o episódio no desencadeamento da sessão de ontem, na saída da qual foi assaltado por uma sensação que reconhece, neste momento, como sinal que anunciava a onda do lúgubre humor que foi se instalando nele, desde então.

O fragmento é do sexto mês de análise. No entanto, o paciente, um homem de quarenta e dois anos, esteve em tratamento (psicoterapias e análises), com algumas interrupções, nesses últimos vinte e cinco anos. Nas sessões seguintes, debruça-se, vez e outra, sobre a "pequena" descoberta desta tonalidade de cor de sua alma em depressão: "desta vez", comenta ele com certa ironia, "ela se aproximou apenas, tentando me envolver na sua lembrança. Mas isso durou só por alguns minutos. Porém, desde cedo, dos meus dezenove anos de idade, essa luz - agonizante, solitária - constituíra, durante muito tempo, minha morada, e sem eu saber. Com os anos, ela encurtara suas estadias e suas visitas tornaram-se menos freqüentes".

Nosso interesse, neste momento, não é a análise do caso, mas enfocar o caráter específico da vivência sensorial do estado depressivo. A tonalidade da percepção sensória destaca-se, adquirindo tal característica, porque deve-se à, ou é concomitante do, seu desligamento do ambiente humano ao qual estava tecida. É esse o ponto crucial. A ameaça de tal desvinculação infiltra o temor de recaída na solitária morada da depressão. A fenomenologia da percepção, a vivência sensorial, deve ser apreendida só nesta perspectiva, ou seja, da transferência e seus desfiladeiros no ambiente de origem.

O efeito de deslumbramento estético no analista pode resvalar a essência da comunicação transferencial. Na escuta deste gênero, contido no fragmento anterior, ocorre a alguns dizer ao paciente, animando-se, algo no espírito de: "olhe, você atingiu o branco e frio fundo da existência humana. É isso mesmo. As artes plásticas demoraram tanto tempo para alcançar a plataforma, a tela branca e aquém dela... Você descobriu... é lindo". Comentário que se coloca a serviço de uma defesa, contratransferencial, ante a experiência primitiva. A vivência do paciente não é de ordem estética, embora pode vir a ser com o surgir das palavras. O modo como o 


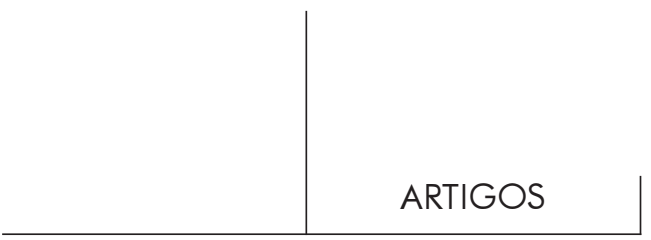

ambiente familiar recua, esfria-se, a ponto de expor a nu as qualidades físicas, da luz neste caso, desinvestidas do tecido afetivo humano no qual são normalmente ancoradas, coloca em relevo, na genealogia do psiquismo, as origens da malha afetiva, "costurada" e formada pela reação "química" dos estímulos sensórios junto às pulsões. Bion identificou e destacou, mais do que outros, as feições de tais estados em que se constata vivências desprovidas das qualidades mais básicas do viver e do sentir humanos. Foi ele, também, quem delineou, de forma sistemática, as origens dos afetos e dos pensamentos, no substrato sensório ${ }^{20}$. Mas, atenção, a vivência sensória é, em si, diferente da reação depressiva. Qual seria a sua "função" neste conjunto?

O processo analítico nos possibilita, muitas vezes, traçar a origem de uma vivência sensória do estado depressivo, remontando-a a uma certa situação vivida junto ao objeto: meses depois, o citado paciente associa a referida tonalidade com a luz que imantava o ar da sala em que passava silencioso as horas junto a uma mãe enlutada do início da adolescência. O que nos parece apenas a ponta de um fio que remonta a vivências muito mais precoces... ${ }^{21}$. Todavia, essa reconstrução não é imprescindível para levantar algumas hipóteses sobre a psicopatologia depressiva e a organização psíquica em questão. A descrição do episódio narrado pelo paciente não representa, em termos da referida desvinculação, o estado mais agudo ou o mais arcaico. Pois o grau de desmantelamento é passível de trazer de volta modalidades do sentir que remontam às "partículas" ou às quotas e intensidades as mais elementares dos estímulos sensoriais. A regressão refere-se tanto ao grau de gravidade do estado depressivo, assim como aos estágios precoces do psiquismo, como se a experiência sensorial aproximasse àquela vivida pelo recém-nascido ou o bebê com poucos dias de vida.

O mesmo paciente evoca, dois meses depois, em pleno verão, outra vivência, de vinte e três anos atrás (quando estava com dezenove anos de idade). A qualidade sensória, no centro desta lembrança, é também da luz, mas desta vez do sol de uma tarde de verão em que foi levado pelos amigos a um passeio na praia, para espairecer. A vivência sensória é nítida:

20. As noções de objetos bizarros, elementos beta, revêrie e função alfa, entre outras, às quais aludimos em nosso trabalho, tentam, justamente, nomear elementos e funções, e seu modo de funcionamento, na construção e na integração do tecido afetivo/representativo do humano. A aplicação esquemática desses conceitos na literatura deixa de aprofundar o entendimento dos mesmos e seus papéis tanto na psicopatologia como na metapsicologia.

21. Cf. o artigo de Donald Meltzer, "Clinical application of Bion's concept 'transformations in hallucinosis", que remonta uma alucinação olfativa de um paciente à vivência infantil junto ao objeto. 


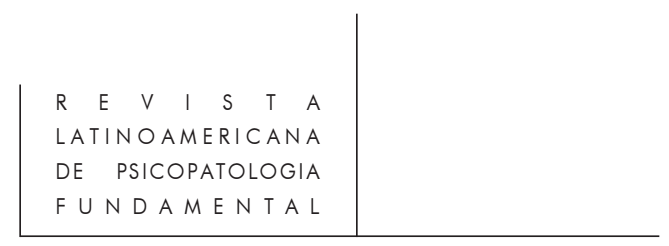

Uma intensidade branca, singular e indescritível da luz do sol: é insuportável e não há como fugir dela. O tempo não passa. Isolamento absoluto; uma distância intransponível o separa dos amigos a sua volta. Não consegue captar ou compreender as frases que emitem; ouve apenas o som, as vozes e poucas palavras, porém desprovidas de sentido. Sente-se aprisionado, cheio do próprio corpo. Cabisbaixo, tenta escapar a dolorosa intensidade da luz lançada sobre o temido panorama dos corpos nus da praia. A luz o enjoa, gera vertigem. Ele faz um esforço, concentra-se para manter o equilíbrio do corpo neste campo agitado, e reza, descrente, pela salvação: a volta para casa, para seu quarto.

Naquele período, gravemente deprimido, encontrava-se recluso em sua casa, junto a sua mãe e irmã, após uma breve internação no hospital psiquiátrico. Passava as manhãs na cama, dormindo. Qualquer contato com os outros lhe era extremamente custoso, mais pelo esforço que o encontro demandava do que pela recusa de estar junto. Vontade não lhe faltava. Ao contrário, almejava ardentemente os contatos, porém qualquer oportunidade o travava, "não gerava liga". Preso dentro de sua "ilha", no vazio que a enchia, a presença de um outro lhe era intolerável. É o que evoca ao redor deste episódio, e acrescenta: "É somente hoje que pude adquirir palavras para um tempo em que não havia tempo, não haviam palavras, salvo em alguns segundos, nos despertares súbitos da madrugada em que um relâmpago da consciência trazia-me a noção da presença de uma personagem, EU, dentro dessa ilha vazia, cuja constância segurava, no limite, esse tipo deplorável de existência".

A lembrança da singular intensidade da luz nos transpõe, então, para o âmago da existência de uma depressão aguda. Logo depois de evocar o incidente, o paciente reflete, estranhando-se: "a luz não deveria ter sido tão intensa assim, pois era uma tarde de verão, entre 16:30 e 18:00 horas, como neste horário e sol de hoje". $\mathrm{Na}$ sessão seguinte, ele identifica esta mesma intensidade, peculiar e insuportável, da luz em todo o período de sua aguda depressão, ao se encontrar fora de casa nas atordoantes tardes de verão.

Quanto maior o recuo depressivo, maior é o desalojamento do universo afetivo humano, e mais desancorados do mesmo o são os estímulos sensoriais, expondo o sujeito ao efeito mais cruel de suas intensidades primárias. O testemunho do paciente nos permite voltar à questão sobre a função do estado depressivo, pois a sequiência clínica coloca em relevo o que tem sido notado desde sempre em relação à patologia depressiva: a cisão. É preciso, no entanto, se ater às palavras do paciente que revelam a preservação mais básica dos contornos psíquicos ("ilha vazia"), afastando, porque incapacitado de assimilar, os estímulos e o agito do mundo que o rodeia. O que nos faz lembrar da preciosa definição de Fédida da depressão como "organização narcísica do vazio", figura primitiva da psique (Fédida, 1999). 


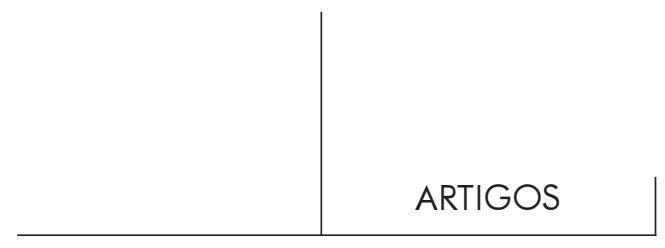

A noção de cisão, do isolar-se e do afastar-se - um verdadeiro recurso para salvaguardar um terreno psíquico de base -, não se aplica de forma estanque ao conjunto da personalidade, como figura nas formulações de splitting (da escola inglesa), mas como uma manutenção de um continente, com rachaduras, de resistências variáveis, e suas derivadas ilhas: o sujeito transformando-se em um verdadeiro arquipélago. Essa seria a cartografia psíquica mais comum de ser encontrada nas patologias depressivas, sobretudo naquelas denominadas de casos fronteiriços, aos quais pertence o paciente anterior.

Qual seria a relevância dessas configurações (cisão, arquipélago) para a função econômica da depressão? Os fragmentos clínicos ilustram como a depressão dá cobertura (como a caverna), ou compensa a falha do objeto. Ou seja, ela funciona, na dimensão energética, como um freio que desacelera a tendência "natural", entrópica, de desintegração. O que, na genealogia do psiquismo, denuncia e flagra uma função lentificadora - "esfriamento" - como condição "termodinâmica" imprescindível aos processos de construção - de integração/apropriação - do tecido familiar (afetivo) humano que compõe o cerne da vivência sensorial ${ }^{22}$.

\section{Conclusão}

Enfocamos, neste artigo, dois momentos ou estágios capitais da diferenciação psíquica, de caráter predominantemente depressivo: o do terreno psíquico primordial (e sua estrutura enquadrante) e o do Eu que surge dentro desse vasto terreno. Apesar de se tratar da instauração do espaço psíquico e um de seus continentes, a exposição desse desenvolvimento foi fornecida em termos energéticos, apontando para os fundamentos econômicos do mesmo. Aludimos apenas aos processos integrativos que mantêm esses conjuntos, suas regiões e unidades. O papel imprescindível do objeto na integração, ou seja em proporcionar, consagrar e sustentar, interiormente, a coesão das estruturas criadas nas diferenciações alcançadas foi apenas apontado, sem, no entanto, explicitar e discutir sua natureza. Por outro lado, a vinheta clínica centrada na vivência sensorial do quadro depressivo teve, como objetivo, exemplificar, em termos econômicos, um dos processos de integração em jogo no qual o objeto desempenha um papel fundamental.

Acreditamos que esses exemplos e desenvolvimentos possam lançar uma nova luz sobre alguns aspectos da ubíqua função da depressão na vida psíquica. Diferenciação e integração, repetimos, que estão no cerne dos curiosos fenômenos

22. Essa seria a feição energética (para qual Freud assinalou inúmeras vezes em relação à atividade da apreensão psíquica e do pensar) - em paralelo àquilo que é necessário às reações e processos anímicos do vivo - que denominamos de continência e tempo. 
termodinâmicos responsáveis pela negentropia, ou seja, por aqueles elementos que determinam esse intervalo que identificamos como vida. A depressão abrigaria, nessa analogia, uma negentropia tributária da diferenciação e integração, tornando a vida psíquica possível.

\section{Referências bibliográficas}

BERLinCK, M.T. (org.). Dor. São Paulo: Escuta, 1999.

Delouya, Daniel. Depressão. São Paulo: Casa do Psicólogo, 2000.

. Tópica, o negativo da depressão originária. Percurso, n. 21, pp. 5-15, 1998.

FÉDIDA, Pierre. O vazio da metáfora e o tempo do intervalo. In Depressão. São Paulo: Escuta, 1999.

Ferenczi, S. (1933). Confusão de línguas entre os adultos e a criança. Obras Completas. São Paulo: Martins Fontes, 1992. v. IV.

Freud, Sigmund (1895). Projeto de uma psicologia. Rio de Janeiro: Imago, 1995. VII. (1905). Três ensaios sobre a sexualidade. E.S.B. Rio de Janeiro: Imago, 1976. v.

(1911). Formulações sobre os dois princípios do funcionamento psíquico. E.S.B. Op. cit. v. XII.

(1912) "Sobre um tipo de degradação da vida amorosa" E.S.B. Op. cit. v. XI.

(1915). As pulsões e seus destinos. E.S.B. Op. cit. v. XIV.

(1920). Além do princípio do prazer. E.S.B. Op. cit. v. XVII.

(1921). Psicologia das massas e análise do eu. E.S.B. Op. cit. v. XVIII.

(1923). O eu e o isso. E.S.B. Op. cit. v. XIX.

(1924). O problema econômico do masoquismo. E.S.B. Op. cit. v. XIX.

(1925). Negação. E.S.B. Op. cit. v. XIX.

(1926). Inibição, sintoma e angústia. E.S.B. Op. cit. v. XX.

(1938). Esboço de psicanálise. E.S.B. Op. cit. v. XXIII.

GREEN, André. Narcisismo primário: estrutura ou estado? In Narcisismo de vida, narcisismo de morte. São Paulo: Escuta, 1989.

KLeIN, Melanie (1935). A contribution to the psychogenesis of manic-depressive states. In The writings of Melanie Klein. New York: Free Press, 1975, pp. 262-90. v. 1.

Melsohn, Isaías. Notas críticas sobre o inconsciente, sentido e significação: a função expressiva e a constituição do sentido. Ide, n. 21, pp. 18-47, 1991.

Meltzer, Donald. Clinical application of Bion's concept "transformations in hallucinosis" In Studies in extended metapsychology. London: Clunie Press, 1986.

Searles, Harold (1968). O esquizofrênico e sua experiência singular do mundo. Percurso 24: 5-18, 2000.

WinnicotT, Donald W. (1963). The value of depression. In Home is where we start from. London: Norton Company, 1986. [Tudo começa em casa. Porto Alegre: Artes Médicas, 1995]. 


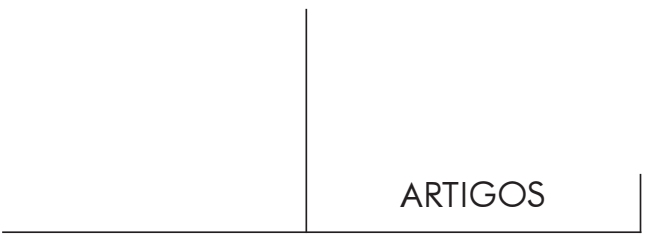

Resumos

Interrogados sobre las preguntas actuales acerca de la depresión - tema propuesto para la primera jornada de esta revista - el presente trabajo sugiere que la depresión nos permite relanzar las preguntas cruciales en relación a la dimensión económica del aparato psíquico, integrandola a otras, tópica y dinámica. La depresión se encuentra en el cerne de un principio que en analogía y biología, condiciona y posibilita el surgimiente de la vida y su permanencia. O sea, abriga dentro de ella un principio paralelo al que rige en la termodinamia, la tendencia negentrópica. En otras palabras, ella conduce la construcción de la vida psíquica a través de dos clases de procesos que posibilitan, en esta analogia, la vida: diferenciación e integración. Algunos momentos y vinhetas clínicos son traidos como ilustración de estos procesos.

Palabras llave: Diferenciación, integración, aquiescencia narcisica, pulsion de muerte

Interrogé sur les questions actuelles sur la dépression - thème des premières journées de cette Revue - ce travail suggère que la dépression permet de relancer quelques questions essentielles à propos de la dimension économique de l'appareil psychique tout en l'intégrant aussi aux dimensions topiques et dynamiques de cet appareil. Faisant l'analogie avec la biologie, la dépression se trouve au cour même d'un principe que conditionne et rend possible l'origine et l'entretien de la vie. La dépression abrite ainsi dans son intérieur un principe parallèle à celui que régit, dans la thermodynamique, la tendance négentropique. En d'autres mots, elle conduit à la construction de la vie psychique à travers deux classes de processus, différentiation et intégration, qui, selon l'analogie proposée, rendent possible la vie. Quelques vignettes cliniques sont apportées pour illustrer ces processus.

Mots clés: Différentiation, intégration, quiescense narcisic, pulsion de mort

This article shows how the phenomenon of depression may enlighten crucial questions related to the economic dimension of the Freudian psychic apparatus, integrating it to its other dimensions, the topical and the dynamic. Depression is intimately related to the analogous principle that enables and conditions the emergence and preservation of life in biological systems. It seems to follow a parallel negentropic tendency which, in thermodynamics, is in contrast to the natural law of entropy. In other words, depression is the expression of a principle that, according to the biological analogy, governs the construction of psychic life through two groups of processes: differentiation and integration. Clinical vignettes illustrate these principles and processes.

Key words: Differentiation, integration, quienscence narcisic, death instinct

Versão inicial recebida em outubro de 2000

Versão revisada recebida em fevereiro de 2001 